\title{
Helicobacter pylori-Specific Immune Response in Maternal Serum, Cord Blood, and Human Milk Among Mothers With and Without Current Helicobacter pylori Infection
}

\author{
MARIA WEYERMANN, CATHLEEN BOROWSKI, GÜNTER BODE, BILGE GÜRBÜZ, \\ GUIDO ADLER, HERMANN BRENNER, AND DIETRICH ROTHENBACHER
}

Department of Epidemiology [M.W., C.B., G.B.,B.G.,H.B.,D.R.], The German Center for Research on Aging, D-69115 Heidelberg, Germany, Department of Internal Medicine I [G.A.], University of Ulm, D-89081 Ulm, Germany

\begin{abstract}
ABST
We assessed the patterns of Helicobacter pylori $(H$. pylori)
specific maternal antibodies in maternal serum, cord blood, and
milk, which might play a role in prevention of $H$. pylori infection
because transferred to the infant. Between November 2000 and
November 2001 , mothers were recruited after delivery of their
offspring. $H$. pylori infection status was determined by ${ }^{13}$ C-urea
breath test (UBT). Specific $H$. pylori antibody profiles were
analysed using commercial $H$. pylori-specific enzyme-linked
immunosorbent assay and Western blots. Among 898 mothers,
$23 \%$ had a current $H$. pylori infection. Median $H$. pylori IgG
antibody titers in serum and cord blood of UBT-positive mothers
were $23.8 \mathrm{U} / \mathrm{mL}$ and $24.0 \mathrm{U} / \mathrm{mL}$, respectively. Whereas preva-
lences of $H$. pylori-specific antibodies in serum of UBT-negative
mothers were clearly lower than those among UBT-positive
\end{abstract}
mothers, patterns of $H$. pylori-specific IgA antibodies in milk were similar among UBT-positive and UBT-negative mothers. Neonates born from $H$. pylori-infected women are provided with large amounts of transplacentally transferred specific $\operatorname{IgG} H$. pylori antibodies. Breast-fed neonates are additionally provided with specific IgA antibodies in human milk. Notably, the latter may also be activated if exposure of the mother to $H$. pylori might have been long time ago and been cleared in the meantime.

(Pediatr Res 58: 897-902, 2005)
Abbrevia
GAP, gastritic and peptic ulcer
H. pylori, Helicobacter pylori
UBT, ${ }^{13} \mathrm{C}$-urea breath test

Infection with $H$. pylori causes chronic gastritis and gastric and duodenal ulcers and has been recognized as a class I carcinogen (1). Recent epidemiologic evidence suggests that the acquisition of $H$. pylori infection occurs in early childhood $(2,3)$ and that the mother might play a key role in transmission, at least in the Western world (2-4).

At birth, the immune system of the newborn is immature and its postnatal expansion and maturation takes time. In the first months of life, IgG antibodies from the mother, which had been transferred transplacentally, as well as secretory $\operatorname{IgA}$ antibodies in milk provided by breast-feeding play an important role for the protection of the infant (5). For pathogens having a mucosal portal of entry, secreted $\operatorname{Ig} \mathrm{A}$ antibodies in

Received May 20, 2004; accepted April 11, 2005.

Correspondence: Maria Weyermann, Ph.D., Department of Epidemiology, The German Center for Research on Aging, Bergheimer Str. 20, D-69115 Heidelberg, Germany: e-mail: weyermanndzfa@aol.com

The study was supported by grants from the Deutsche Forschungsgemeinschaft (BR 1704/3-1, BR 1704/3-2, BR 1704/3-3)

DOI: 10.1203/01.PDR.0000181370.67474.FD human milk play a major role in protecting infants from infection (6). Because $H$. pylori infection is predominantly acquired in early childhood, but rarely within the first months of life (2), maternal antibody transfer to the infant may be important in prevention of acquisition of infection.

Whereas several studies have described the transplacental transfer of maternal $H$. pylori-specific serum IgG antibodies (7-10), the possible transfer of $H$. pylori-specific IgA antibodies in human milk by breast-feeding has only been investigated among small samples of Gambian mothers and their children (11-14). There are no epidemiologic data from industrialized countries describing the specific $H$. pylori antibody profiles in serum, cord blood, and human milk.

Therefore, the aim of this study was to assess the $H$. pylori-specific immune response in maternal serum, cord blood, and human milk among mothers with current $H$. pylori infection to elucidate the possible protective mechanisms of maternal antibody transfer to the infant. Because the mother's antibody repertoire reflects her history of infectious diseases before pregnancy (15), we also evaluated the $H$. pylori-specific 
immune response in maternal serum and human milk among mothers without current $H$. pylori infection.

\section{METHODS}

Study design and study population. All women who came to the Department of Gynecology and Obstetrics at the University of Ulm between November 2000 and November 2001 for the delivery of their baby were recruited for the study. In Germany, women on average stay in the hospital for about 5 days after delivery, and recruitment was done during this time. During the time of recruitment, the Department of Gynecology and Obstetrics at the University of Ulm was the only major department of obstetrics in the study area and served the vast majority of child-bearing women in the city of Ulm and the nearby communities.

To obtain a birth cohort of healthy and mature babies, we excluded women who gave birth at less than 32 gestational weeks, had a baby of less than $2500 \mathrm{~g}$ birth weight, or whose infant was transferred to inpatient pediatric care immediately after delivery. Furthermore we excluded women with no understanding of German, Turkish, or Russian language, as well as all women who left the hospital immediately after birth.

Participation was voluntary and informed consent was obtained in each case. The study was approved by the Ethics Board of the University of Ulm and of the Physicians' Boards of the states of Baden-Wuerttemberg and Bavaria.

Data collection. All mothers underwent standardized interviews conducted by trained interviewers during hospitalization after delivery. Interviews included detailed questions about housing and living conditions, lifestyle factors, medical history, and health status during pregnancy.

The interview was also offered in Turkish and Russian as this was the mother tongue of some of the mothers. A standardized form was used to collect laboratory and anthropometric data during pregnancy from the mother's pregnancy health chart. Cord blood samples were collected immediately after delivery, and serum samples of the mothers were collected after delivery in combination with the routine drawing of blood in the hospital. Samples of cord blood and serum were aliquoted and frozen at $-80^{\circ} \mathrm{C}$ until analysis was performed. All mothers included at baseline were contacted by phone 6 weeks post partum and were asked whether they were breast-feeding at this time. A trained nurse then visited all women who were still breast-feeding and collected $10 \mathrm{~mL}$ of human milk, which was immediately cooled and frozen at $-80^{\circ} \mathrm{C}$ within 24 hours. In almost all cases, milk samples were collected by a trained nurse from both breasts by manual expression before feeding. In rare cases, milk samples were collected by the mothers themselves and/or by means of a pump.

Laboratory analyses. Active infection with $H$. pylori among the mothers was determined concurrent with the interviews using the ${ }^{13} \mathrm{C}$-urea breath test (UBT). The UBT is based on the principle that $H$. pylori is a strong producer of urease, an enzyme that splits urea into ammonium and $\mathrm{CO}_{2}$ (16). First, an initial breath sample was collected in a plastic bag. The women then received $200 \mathrm{~mL}$ of apple juice that contained $75 \mathrm{mg}$ of nonradioactive labeled ${ }^{13} \mathrm{C}$-urea (Mass Trace, Woburn, MA). After 30 minutes, a second breath sample was collected. The breath samples were analyzed with an isotope selective nondispersive infrared spectrometer (NDIRS; Wagner Analytical Systems, Bremen, Germany). A change of the ${ }^{13} \mathrm{CO}_{2} /{ }^{12} \mathrm{CO}_{2}$ ratio over baseline of more than ${ }^{4} / 00$ was considered positive. Sensitivities and specificities of the ${ }^{13} \mathrm{C}$-urea breath test close to $100 \%$ have consistently been reported, suggesting the test is the gold standard in subjects in whom endoscopy is not indicated (16).

We used commercial enzyme-linked immunosorbent assays (GAP; Bio-Rad Laboratories Diagnostics Group, Munich, Germany) to analyze serum and cord blood samples of the UBT-positive mothers for $H$. pylori IgG antibodies and human milk samples of the UBT-positive mothers as well as of a random sample of 78 UBT-negative mothers for $H$. pylori IgA antibodies. The serum and cord blood samples of the UBT-positive mothers as well as the serum samples of the UBT-negative mothers were further analyzed for the presence of specific IgG antibodies against $H$. pylori-specific antigens with a commercial Western blot method (H. pylori-Western blot; AID, Strassberg, Germany) as described previously (17). The same method was used to further analyze for the presence of specific IgA antibodies against $H$. pylori-specific antigens in the human milk samples.

Because these test kits were developed for antibody detection in serum, for the analyses in human milk the manufacturer's instructions were optimized by a checker board titration (ELISA: 30-minute incubation time instead of 10 minutes, $25-\mu \mathrm{L}$ sample volume diluted in $1 \mathrm{~mL}$ buffer instead of $5 \mathrm{~mL}$; Western blot: 30-minute incubation time instead of 10 minutes, $80-\mu \mathrm{L}$ sample volume instead of $20 \mu \mathrm{L}$ ). Because of the modified method, IgA contents analyzed with ELISA were reported only as optical density [OD/mL]. According to the manufacturer's instructions, in Western blot analysis levels $\geq 20 \%$ were considered positive in IgG analyses and levels $\geq 10 \%$ were considered positive in $\operatorname{IgA}$ analyses.

The sensitivity and the specificity of the IgG GAP ELISA were reported to be $94.9 \%$ and $92.9 \%$, respectively (18), and the sensitivity and the specificity of the IgA GAP ELISA were reported to be $96.4 \%$ and $80.5 \%$, respectively (19). Pertinent data have not been reported for $H$. pylori IgA antibodies in human milk samples. However, the aim of our $H$. pylori $\operatorname{IgA}$ analysis in human milk samples was only to compare the patterns of $H$. pylori-specific $\operatorname{IgA}$ antibodies in human milk samples of women with and without current $H$. pylori infection (determined by UBT) and not the diagnosis of $\mathrm{H}$. pylori infection.

Statistical analyses. We first carried out descriptive analyses concerning sociodemographic characteristics of the mothers and assessed the relation between $H$. pylori infection status and sociodemographic characteristics of the mothers. We then carried out descriptive analyses concerning $H$. pylorispecific antibody titers of $H$. pylori-infected mothers in maternal serum, cord blood, and human milk as determined by ELISA. Correlations between antibody titers were determined by Spearman correlation coefficients. Furthermore, we described the prevalence of $H$. pylori-specific antigens determined by Western blot analyses in serum, cord blood, and human milk among UBT-positive mothers as well as in maternal serum of all UBT-negative mothers and in human milk in a random sample of 78 UBT-negative mothers. The $\kappa$ coefficient with $95 \%$ confidence interval was used to assess intraindividual agreement levels between specific $H$. pylori antibodies in serum and cord blood and serum and human milk, respectively. The $\kappa$ coefficient corrects the proportion of observed agreement for the proportion of expected agreement by chance. $\kappa$ values were interpreted as "excellent" if $>0.75$, as "fair to good" if between 0.40 and 0.75 , and as "poor" if $<0.40$ (20).

All analyses were carried out with the SAS statistical software package (SAS Language: Reference. Version 8, 1st ed., SAS Institute, Inc., Cary, NC).

\section{RESULTS}

Overall, 1066 among all 1593 eligible mothers (67\%) participated in the study. Of these, we had to exclude 168 mothers from this analysis because of a missing result of the UBT $(n=$ $1)$ or recent antibiotic intake $(n=167)$, leading to a sample size of 898 mothers for this analysis.

Table 1 shows the basic characteristics and prevalence of $H$. pylori infection according to the UBT result of the 898 mothers in the study population. Mean age of the mothers was 30.7

Table 1. Basic characteristics and prevalence of Helicobacter pylori infection according to ${ }^{13} \mathrm{C}$-urea breath test of mothers in the study sample

\begin{tabular}{|c|c|c|c|}
\hline \multirow[b]{2}{*}{ Characteristics } & \multirow{2}{*}{$\frac{\text { All }}{\text { No. }}$} & \multicolumn{2}{|c|}{$\begin{array}{c}\text { H. pylori } \\
\text { Prevalence }\end{array}$} \\
\hline & & No. & (row \%) \\
\hline Total & 898 & 206 & 22.9 \\
\hline \multicolumn{4}{|l|}{ Age, $y$} \\
\hline $16-25$ & $164(18.2)$ & 62 & 37.8 \\
\hline $26-35$ & $569(63.4)$ & 120 & 21.1 \\
\hline $36-45$ & $165(18.4)$ & 24 & 14.6 \\
\hline \multicolumn{4}{|l|}{ Education, $\mathrm{y}$} \\
\hline$\leq 9$ & $220(24.5)$ & 89 & 40.4 \\
\hline $10-11$ & $339(37.8)$ & 65 & 19.1 \\
\hline$\geq 12$ & $313(34.9)$ & 42 & 13.4 \\
\hline \multicolumn{4}{|l|}{ Nationality } \\
\hline German & $755(84.1)$ & 115 & 15.2 \\
\hline Turkish & $51(5.7)$ & 38 & 74.5 \\
\hline Other & $92(10.2)$ & 53 & 57.6 \\
\hline \multicolumn{4}{|l|}{ Breast-feeding } \\
\hline Never & $57(6.6)$ & 15 & 26.3 \\
\hline Ever & $802(93.4)$ & 179 & 22.3 \\
\hline \multicolumn{4}{|c|}{ Six weeks after birth } \\
\hline Yes & $649(80.9)$ & 140 & 21.6 \\
\hline No & $136(17.0)$ & 35 & 25.7 \\
\hline
\end{tabular}


years (SD 5.2), and about $25 \%$ had less than 10 years of education. Most women (84.1\%) were of German nationality, and $5.7 \%$ and $10.2 \%$ were of Turkish or other nationality, respectively. Of the 898 mothers 206 (22.9\%) were UBT positive. In general, prevalence of infection was higher in younger mothers and in mothers with low level of school education. Of the 755 German mothers, only $115(15.2 \%)$ were infected with $\mathrm{H}$. pylori, whereas $74.5 \%$ and $57.6 \%$ of the mothers of Turkish or other than German or Turkish nationality were infected with $H$. pylori, respectively.

Six weeks after delivery, 859 (95.7\%) mothers could be successfully contacted again. Of these, $802(93.4 \%)$ mothers had ever breast-fed their infants and 649 mothers $(75.6 \%)$ were still breast-feeding their infant 6 weeks after birth. Prevalence of $\mathrm{H}$. pylori infection was $22.3 \%$ in mothers who had ever breast-fed their child and $21.6 \%$ in mothers who were still breast-feeding their child 6 weeks after birth.

A description of $H$. pylori antibody levels in maternal serum, cord blood, and human milk among UBT-positive mothers determined by ELISA is shown in Table 2. The median of $H$. pylori-specific IgG in maternal serum and cord blood was 23.8 and $24.0 \mathrm{U} / \mathrm{mL}$, respectively, and the correlation coefficient between serum and cord blood levels was $0.90(p<0.0001)$. The median of the antibody level of $H$. pylori-specific IgA in human milk of UBT-positive mothers was $0.36 \mathrm{OD} / \mathrm{mL}$. The correlation coefficient between $H$. pylori-specific IgG titers in maternal serum and $H$. pylori-specific $\operatorname{IgA}$ in human milk was $0.32(p=0.0002)$.

Prevalence of $H$. pylori-specific antibodies determined by Western blot in maternal serum, cord blood, and human milk of H. pylori-infected mothers is shown in Table 3. The immunoresponse in serum and cord blood of UBT-positive mothers was characterized by $\mathrm{IgG}$ antibodies predominantly against low molecular weight antigens of $14 \mathrm{kd}(65.2 \%$ and $71.1 \%)$ and $29 \mathrm{kd}(61.2 \%$ and $62.6 \%)$ as well as against the CagA antigen $(120 \mathrm{kd})(50.3 \%$ and $56.2 \%)$. $\mathrm{K}$ coefficients as measurements for intraindividual agreement of specific $H$. pylori antibodies in maternal serum and cord blood ranged between 0.69 and 0.86 . In human milk of UBT-positive mothers, the immunoresponse was characterized by IgA antibodies predominantly against the urease antigens with $66 \mathrm{kd}$ (UreB) (prevalence: $32.9 \%)$ and $29 \mathrm{kd}$ (UreA) $(48.9 \%)$ and against the antigen of $14 \mathrm{kd}(35.8 \%)$. K coefficients as measurements for intraindividual agreement of specific $H$. pylori antibodies in maternal serum and human milk were 0.20 and lower.

In UBT-negative mothers, the highest prevalence (27.9\%) of H. pylori-specific IgG antibodies in maternal serum was seen for the $29 \mathrm{kd}$ urease antigen (Table 4). Prevalence of antibodies against the other $H$. pylori-specific antigens ranged between $1.5 \%$ (17-kd antigen) and 9.5\% (120-kd antigen). In human milk of a random sample of UBT-negative mothers prevalences of $H$. pylori-specific $\operatorname{IgA}$ antibodies were of similar magnitude as in human milk of UBT-positive mothers. For some antigens, the prevalence was even higher. The immunoresponse against $H$. pylori was characterized by IgA antibodies predominantly against the urease antigens with $66 \mathrm{kd}$ (UreB) (48.7\%) and $29 \mathrm{kd}(\mathrm{UreA})(43.6 \%)$, and against the antigen of $14 \mathrm{kd}(53.9 \%)$. $\mathrm{K}$ coefficient as measurement for intraindividual agreement of specific $H$. pylori antibodies in maternal serum and human milk was 0.46 for antibodies against the antigen of $25 \mathrm{kd}$. K coefficients for the other specific $\mathrm{H}$. pylori antibodies were 0.12 and lower. With respect to the $87-\mathrm{kd}$ (VacA), the 29-kd (UreA), the 19- kd, and the 17-kd antibodies absolutely no agreement was evident.

\section{DISCUSSION}

We studied the occurrence and patterns of specific $H$. pylori antibodies in maternal serum and cord blood and samples of human milk in a group of 898 mothers in Germany to determine the degree of passive immunity transferred from women with and without current $H$. pylori infection to their infants. The immunoresponse in serum and cord blood among UBTpositive mothers was characterized by IgG antibodies predominantly against the CagA antigen (120 kd) as well as against low molecular weight antigens of 14 and $29 \mathrm{kd}$ with a very high degree of intraindividual agreement. Transplacental transfer of these $H$. pylori-specific IgG antibodies from the mother to the newborn may contribute to protective immunity of the newborn within the first months of life. The innate immune system is further supported by large amounts of specific $H$. pylori $\operatorname{IgA}$ antibodies in maternal milk. Notably, the latter may also be reactivated if exposure of the mother to $H$. pylori might have been long time ago and been cleared in the meantime.

Based on the ${ }^{13} \mathrm{C}$-urea breath test $22.9 \%$ of mothers included in our study had a current $H$. pylori infection. Our findings regarding the very strong association between $H$. pylori infection and ethnic background are in agreement with previous reports from this and other countries (4). Our study is also consistent with previous findings that $H$. pylori infection in adults is strongly associated with certain sociodemographic factors like education $(21,22)$. The inverse association between H. pylori infection and age in our bivariate analysis appears surprising on first view but can be explained by confounding

Table 2. H. pylori antibody levels in maternal serum, cord blood, and human milk in UBT-positive mothers

\begin{tabular}{|c|c|c|c|c|c|c|}
\hline & \multirow[b]{2}{*}{ No. } & \multirow[b]{2}{*}{$\begin{array}{c}\text { Median } \\
\text { (25th-75th percentile) }\end{array}$} & \multicolumn{4}{|c|}{ Results for subjects with values for both } \\
\hline & & & No. & $\begin{array}{c}\text { Median } \\
\text { (25th-75th } \\
\text { percentile) }\end{array}$ & $\begin{array}{l}\text { Correlation } \\
\text { coefficient* }\end{array}$ & $p$ \\
\hline Maternal serum $\mathrm{IgG}, \mathrm{U} / \mathrm{mL}$ & 193 & $23.8(13.5-38.3)$ & 180 & $23.9(13.5-38.4)$ & 0.90 & $<0.0001$ \\
\hline Cord blood $\mathrm{IgG}, \mathrm{U} / \mathrm{mL}$ & 185 & $24.0 \quad(12.6-38.0)$ & 180 & $23.9(12.5-38.0)$ & & \\
\hline Maternal serum $\mathrm{IgG}, \mathrm{U} / \mathrm{mL}$ & 193 & $23.8(13.5-38.3)$ & 133 & $22.8(11.2-37.0)$ & 0.32 & 0.0002 \\
\hline Human milk $\mathrm{IgA}, \mathrm{OD} / \mathrm{mL}$ & 137 & $0.36(0.23-0.63)$ & 133 & $0.36(0.23-0.63)$ & & \\
\hline
\end{tabular}

* Spearman correlation coefficient. 
Table 3. Prevalence of specific H. pylori antibodies in maternal serum compared to cord blood and human milk in women with positive UBT result (current $H$. pylori infection)

\begin{tabular}{|c|c|c|c|c|c|c|c|c|c|}
\hline \multirow[b]{2}{*}{ H. pylori-specific antibodies } & \multicolumn{2}{|c|}{$\begin{array}{l}\text { Serum IgG } \\
(n=201)\end{array}$} & \multicolumn{2}{|c|}{$\begin{array}{l}\text { Cord blood IgG } \\
\quad(n=187)\end{array}$} & \multirow[b]{2}{*}{$\kappa(95 \% \mathrm{CI})^{*}$} & \multicolumn{2}{|c|}{$\begin{array}{l}\text { Human milk IgA } \\
\quad(n=137)\end{array}$} & \multirow{2}{*}{\multicolumn{2}{|c|}{$\kappa(95 \% \mathrm{CI})^{*}$}} \\
\hline & No. & $\%$ & No. & $\%$ & & No. & $\%$ & & \\
\hline 87 kd (VacA) & 75 & 37.3 & 76 & 40.6 & $0.69(0.59-0.80)$ & 10 & 7.3 & 0.013 & $(-0.10$ to 0.18$)$ \\
\hline 66 kd (UreB) & 71 & 35.3 & 70 & 37.4 & $0.73(0.63-0.83)$ & 45 & 32.9 & 0.20 & (0.03 to 0.37$)$ \\
\hline $29 \mathrm{kd}$ (UreA) & 123 & 61.2 & 117 & 62.6 & $0.70(0.59-0.81)$ & 67 & 48.9 & 0.04 & $(-0.13$ to 0.20$)$ \\
\hline $25 \mathrm{kd}$ & 75 & 37.3 & 65 & 34.8 & $0.86(0.78-0.94)$ & 13 & 9.5 & 0.20 & $(0.08-0.33)$ \\
\hline $17 \mathrm{kd}$ & 9 & 4.5 & 11 & 5.9 & $0.79(0.59-0.99)$ & 3 & 2.2 & -0.03 & $(-0.06$ to -0.01$)$ \\
\hline $14 \mathrm{kd}$ & 131 & 65.2 & 133 & 71.1 & $0.77(0.68-0.87)$ & 49 & 35.8 & 0.18 & $(0.04$ to 0.32$)$ \\
\hline
\end{tabular}

$* \kappa$ coefficient with $95 \%$ confidence interval between serum IgG and cord blood IgG, and serum IgG and human milk IgA, respectively, in subjects with both materials available.

Table 4. Prevalence of specific H. pylori antibodies in serum of all UBT-negative women (without current $H$. pylori infection) and in human milk of a random sample of UBT-negative women

\begin{tabular}{|c|c|c|c|c|c|c|}
\hline H. pylori-specific antibodies & \multicolumn{2}{|c|}{ Serum IgG $(n=653)$} & \multicolumn{2}{|c|}{ Human milk $\operatorname{IgA}(n=78)$} & \multicolumn{2}{|r|}{$\kappa(95 \% \mathrm{CI})^{*}$} \\
\hline $120 \mathrm{kd}(\mathrm{CagA})$ & 62 & 9.5 & 4 & 5.1 & 0.12 & $(-0.20 ; 0.44)$ \\
\hline $66 \mathrm{kd}(\mathrm{UreB})$ & 51 & 7.8 & 38 & 48.7 & 0.11 & (0.01 to 0.21$)$ \\
\hline $29 \mathrm{kd}$ (UreA) & 182 & 27.9 & 34 & 43.6 & -0.003 & $(-0.22$ to 0.22$)$ \\
\hline $25 \mathrm{kd}$ & 34 & 5.2 & 8 & 10.3 & 0.46 & (0.09 to 0.82$)$ \\
\hline $14 \mathrm{kd}$ & 57 & 8.7 & 42 & 53.9 & 0.08 & $(-0.05$ to 0.22$)$ \\
\hline
\end{tabular}

$* \kappa$ coefficient with $95 \%$ confidence interval between serum $\operatorname{IgG}$ and human milk $\operatorname{IgA}$ in subjects with both materials available.

by ethnic background (mean age of mothers of German nationality was higher than mean age of mothers of other than German nationality), and socioeconomic factors (older mothers more often had a higher level of education) (data not shown).

In agreement with previous reports $(9,10)$, comparisons of antibody titers in maternal and cord blood in our study showed a high degree of correlation, an indication of direct placental transfer of $\mathrm{IgG}$ antibodies before birth. These maternal $\mathrm{IgG}$ antibodies may last as long as 6 months post partum and may help to protect the child within the first months of life while its own immune system matures.

Whereas maternal serum antibodies are transferred via placenta to the serum of the newborn (23), human milk antibodies are active within the newborn's gut and influence the gut flora (24). In our study, the H. pylori-specific immunoresponse in human milk was characterized by IgA antibodies predominantly against the urease antigens with $66 \mathrm{kd}(\mathrm{UreB})$ and $29 \mathrm{kd}$ (UreA), and against the antigen of $14 \mathrm{kd}$. To our knowledge, until now, only Weaver and others (11-14) had determined specific $H$. pylori antibodies in human milk. Among Gambian women they reported a protective effect of high IgA levels against $H$. pylori infection in infants. The band associated most strongly with protection against $H$. pylori infection has been shown to correspond to the 66-kd subunit of $H$. pylori urease. Weaver et al. concluded that specific human milk IgA may have a crucial role in delaying the onset of $H$. pylori infection.

In our analyses, $\kappa$ coefficients of 0.20 and lower indicated a very poor degree of intraindividual agreement of specific $H$. pylori $\mathrm{IgG}$ antibodies in maternal serum and specific $H$. pylori IgA antibodies in human milk. These differences might illus- trate the possible importance of the genetic background of the host and of $\mathrm{H}$. pylori in modulating the immune response of the host (25). Furthermore, prevalence of $H$. pylori specific $\operatorname{Ig} \mathrm{A}$ antibodies in human milk of UBT-negative mothers was similar when compared with prevalence of UBT-positive mothers. The common presence of specific $H$. pylori IgA antibodies in human milk from mothers without current $H$. pylori infection strongly suggests a major role of previous exposure to $H$. pylori and the activation of the immunologic memory in the maternal secretory immune system (5). Microbes entering the gut will be brought into the Peyer's patches where they stimulate B lymphocytes committed to the production of specific $\mathrm{IgG}$ antibodies. The lactogenic hormones produced toward the end of pregnancy induce a development of the mammary gland, which also results in migration of the B lymphocytes from the Peyer's patches into the glands. This enteromammaric link explains why the milk always contains protective $\operatorname{Ig} \mathrm{A}$ antibodies against the microbes to which the mother was or is still exposed in her gut (5). Current knowledge implies that acquisition of $H$. pylori seems to occur predominantly in childhood and infection seems to be relatively stable in juveniles and adults $(2,3)$. However, in early childhood, $H$. pylori infection might not be stable $(26,27)$, and in adults a transient nature of $H$. pylori infection has been reported. Lifestyle factors such as alcohol consumption and antibiotic treatment may be factors potentially supporting an incidental loss of the infection (28-31).

When looking at our data, the following limitations should be kept in mind. Weaning influences the concentrations of certain constituents of milk as well as total milk production (6). 
However, in our study population, the vast majority of mothers (130 of 137 among $H$. pylori infected mothers, 74 of 78 among $H$. pylori uninfected mothers) were still breast-feeding their children exclusively at the time that the milk samples were collected and had not started weaning. Therefore, it is unlikely that weaning may have influenced the concentrations of specific $H$. pylori antibodies in human milk determined in our study population. Furthermore, volume of collected milk specimen was only $10 \mathrm{~mL}$ of each mother and measurements of small specimen volumes may not necessarily reflect the measurements in more complete collections of human milk.

There was a 6-week interval between collection of maternal blood and milk in our study. However, given that $H$. pylori infection appears to be quite stable in adults, a potential change in $H$. pylori infection status within this 6-week interval is very unlikely.

The antibodies that we used in the human milk analyses were directed against IgA monomers and not against secretory $\operatorname{IgA}$. As secretory IgA comprises the majority of the IgA in human milk, most of the antibodies against $H$. pylori in human milk may have been secretory IgA.

The exclusion criteria that were used to define our study population ( $<32$ gestational weeks, babies of $<2500 \mathrm{~g}$ birth weight, transfer of the baby to inpatient pediatric care immediately after delivery) may be caused by reasons like poor nutrition, perinatal infections, other diseases, or certain medical treatments, but unfortunately we have no information about the reasons that led to a condition that caused an exclusion.

Furthermore, our results concerning the $H$. pylori specific IgG and IgA antibodies of $H$. pylori-infected and noninfected mothers analyzed by Western blot analyses show only the prevalences of these antibodies and contain no information about the levels of the respective antibodies.

Finally, we cannot completely rule out the possibilities of some antigenic cross-reactivities in our Western blot analyses. However, in our analysis, we have only considered bands that are thought to be specific $(25 \mathrm{~d}, 17 \mathrm{D}, 14 \mathrm{kd})$ or that are highly specific to H. pylori (120 kd (CagA), $87 \mathrm{kd}$ (VacA), $66 \mathrm{kd}$ (UreB), $29 \mathrm{kd}$ (UreA), $19 \mathrm{kd}$ ), and we have not considered the band representing the flagellar complex of $H$. pylori (in our Western blot analysis visible as 67-kd bands) because this protein has been shown to be immunologically cross-reactive among flagellated bacteria of various species (32). Also, antigenic cross-reactivity between the urease B protein from Clostridium perfringens and that of $H$. pylori has been reported. However, since only $2 \%$ of the clostridial strains were found to be urease positive and since infections due to $C$. perfringens are very rare in the general population, this cross-reaction might not be of relevance for the interpretation of $H$. pylori immunoblots (32).

The question is whether breast-feeding protects against active $H$. pylori infection in early childhood, and if so, what proportion of this protective effect is attributed to specific $H$. pylori antibodies in human milk, is unclear. Whereas in a large population-based sample of preschool children in the same study area in South Germany, our study group found no protective effect of breast-feeding against $H$. pylori infection (33), Thomas et al. (14) and others found a positive relation between the amount of anti-H. pylori $\operatorname{IgA}$ in human milk and age at acquisition of the infection among Gambian children. They concluded that specific human milk IgA may have a crucial role in delaying the onset of $H$. pylori infection. However, human milk contains a large number of other bioactive compounds that may also give specific and nonspecific protection against $H$. pylori, as demonstrated for lactoferrin by Miehlke et al. (34). Furthermore, the fact that mice lacking antibodies can be protected by immunization against $H$. pylori suggests, that humoral immune response is not essential for protection (35).

In summary, our large-scale epidemiologic study suggests that neonates born from $H$. pylori-infected women are provided with a large amount of specific $\operatorname{IgG} H$. pylori antibodies, which are transferred transplacentally. Breast-fed neonates are additionally provided with large amounts of specific IgA antibodies in human milk. The latter may even be provided if the mother has already lost $H$. pylori infection. Further studies are needed to investigate the role of $H$. pylori antibodies in human milk and in cord blood in preventing $H$. pylori infection in early life.

\section{REFERENCES}

1. International Agency for Research on Cancer, World Health Organization 1994 Infection with Helicobacter pylori. In: IARC, Monogr Eval Carcinog Risks Hum, Schistosomes, liver flukes and Helicobacter pylori. Lyon, 60:177-240

2. Rothenbacher D, Inceoglu G, Bode G, Brenner H 2000 Acquisition of Helicobacter pylori infection in a high-risk population occurs within the first 2 years of life. J Pediatr 136:744-748

3. Webb PM, Knight T, Greaves S, Wilson A, Newell DG, Elder J, Forman D 1994 Relationship between infection with Helicobacter pylori and living conditions in childhood: evidence for person to person transmission in early life. BMJ 308:750753

4. Rothenbacher D, Brenner H 2003 Burden of Helicobacter pylori and H. pylori-related diseases in developed countries: recent developments and further implications. Microbes Infect 5:693-703

5. Hanson LÅ, Korotkova M, Håversen L, Mattsby-Baltzer I, Hahn-Zoric M, Silfverdal SA, Strandvik B, Telemo E 2002 Breast-feeding, a complex support system for the offspring. Pediatr Int 44:347-352

6. Van de Perre P 2003 Transfer of antibody via mother's milk. Vaccine 21:3374-3376

7. Blecker U, Lanciers S, Keppens E, Vandenplas Y 1994 Evolution of Helicobacter pylori positivity in infants born from positive mothers. J Pediatr Gastroenterol Nutr 19:87-90

8. Gold BD, Khanna B, Huang LM, Lee CY, Banatvala N 1997 Helicobacter pylor acquisition in infancy after decline of maternal passive immunity. Pediatr Res 41:641-646

9. Kitagawa M, Natori M, Katoh M, Sugimoto K, Omi H, Akiyama Y, Sago H 2001 Maternal transmission of Helicobacter pylori in the perinatal period. J Obstet Gynaecol Res 27:225-230

10. Bunn JE, Thomas JE, Harding M, Coward WA, Weaver LT 2003 Placental acquisition of maternal specific IgG and Helicobacter pylori colonization in infancy. Helicobacter 8:568-572

11. Thomas JE, Austin S, Dale A, McClean P, Harding M, Coward WA, Weaver LT 1993 Protection by human milk IgA against Helicobacter pylori infection in infancy. Lancet 342:121

12. Weaver LT 1995 Aspects of Helicobacter pylori infection in the developing and developed world. Helicobacter pylori infection, nutrition and growth of West African infants. Trans R Soc Trop Med Hyg 89:347-350

13. Bunn JE, Thomas JE, Harding M, Arthur H, Oostenfeld E, Weaver LT 1996 Maternal milk anti-H. pylori IgA modulates pattern of $H$. pylori infection in infancy. J Pediatr Gastroenterol Nutr 22:416 (abstract)

14. Thomas JE, Bunn JE, Kleanthous H, Monath TP, Harding M, Coward WA, Weaver LT 2004 Specific immunoglobulin A antibodies in maternal milk and delayed Helicobacter pylori colonization in Gambian infants. Clin Infect Dis 39:1155-1160

15. Zinkernagel RM 2001 Maternal antibodies, childhood infections, and autoimmune diseases. N Engl J Med 345:1331-1335

16. Vaira D, Gatta L, Ricci C, Miglioli M 2002 Diagnosis of Helicobacter pylori infection. Aliment Pharmacol Ther 16(suppl 1):16-23

17. Rokkas T, Ladas S, Liatsos C, Petridou E, Papatheodorou G, Theocharis S, Karameris A, Raptis S 1999 Relationship of Helicobacter pylori CagA status in gastric cell proliferation and apoptosis. Dig Dis Sci 44:487-493 
18. Sim JG, Kim EC, Seo JK 1996 The role of serology in the diagnosis of Helicobacter pylori infection in children. Clin Pediatr (Phila) 34:458-462

19. Martin-de-Argila C, Boixeda D, Canton R, Valdezate S, Mir N, De Rafael L, Gisbert JP, Baquero F 1997 Usefulness of combined IgG and IgA antibody determination for serodiagnosis of Helicobacter pylori infection. Eur J Gastroenterol Hepatol 9:1191-1196

20. Fleiss JL 1981 Statistical methods for rates and proportions. Wiley, New York

21. Rothenbacher D, Bode G, Berg G, Knayer U, Gonser T, Adler G Brenner H 1999 Helicobacter pylori among preschool children and their parents: evidence for parentchild transmission. J Infect Dis 179:398-402

22. Rothenbacher D, Bode G, Winz T, Berg G, Adler G, Brenner H 1997 H pylori in out-patients of a general practitioner: prevalence and determinants of current infection. Epidemiol Infect 119:151-157

23. Saji F, Samejima Y, Kamiura S, Koyama M 1999 Dynamics of immunoglobulins at the feto-maternal interface. Rev Reprod 4:81-89

24. Zinkernagel RM 2003 On natural and artificial vaccination. Annu Rev Immunol 21:515-546

25. Del Giudice G, Michetti P 2004 Inflammation, immunity and vaccines for Helicobacter pylori. Helicobacter 9:23-28

26. Kumagai T, Malaty HM, Graham DY, Hosogaya S, Misawa K, Furihata K, Ota H, Sei C, Tanaka E, Akamatsu T, Shimizu T, Kiyosawa K, Katsuyama T 1998 Acquisition versus loss of Helicobacter pylori infection in Japan: results from an 8-year birth cohort study. J Infect Dis 178:717-721

27. Perri F, Pastore M, Clemente R, Festa V, Quitadamo M, Niro G, Conoscitore P, Rutgeerts $\mathrm{P}$, Andriulli A 1998 Helicobacter pylori infection may undergo spontaneous eradication in children: a 2-year follow-up study. J Pediatr Gastroenterol Nutr 27:181-183
28. Brenner H, Berg G, Lappus N, Kliebsch U, Bode G, Boeing H 1999 Alcohol consumption and Helicobacter pylori infection: results from the German National Health and Nutrition Survey. Epidemiology 10:214-218

29. Brenner H, Bode G, Adler G, Hoffmeister A, Koenig W, Rothenbacher D 2001 Alcohol as gastric disinfectant? The complex relationship between alcohol consumption and current Helicobacter pylori infection. Epidemiology 12:209-214

30. Murray LJ, Lane AJ, Harvey IM, Donovan JL, Nair P, Harvey RF 2002 Inverse relationship between alcohol consumption and active Helicobacter pylori infection: the Bristol Helicobacter project. Am J Gastroenterol 97:2750-2755

31. Rothenbacher D, Bode G, Brenner H 2002 Dynamics of Helicobacter pylori infection in early childhood in a high-risk group living in Germany: loss of infection higher than acquisition. Aliment Pharmacol Ther 16:1663-1668

32. Lepper PM, Möricke A, Vogt K, Bode G, Trautmann M 2004 Comparison of different criteria for interpretation of immunoglobulin $\mathrm{G}$ immunoblotting results for diagnosis of Helicobacter pylori infection. Clin Diagn Lab Immunol 11:569-576

33. Rothenbacher D, Bode G, Brenner H 2002 History of breastfeeding and Helicobacter pylori infection in pre-school children: results of a population-based study from Germany. Int J Epidemiol 31:632-637

34. Miehlke S, Reddy R, Osato MS, Ward PP, Conneely OM, Graham DY 1996 Direct activity of recombinant human lactoferrin against Helicobacter pylori. J Clin Microbiol 34:2593-2594

35. Garhart CA, Nedrud JG, Heinzel FP, Sigmund NE, Czinn SJ 2003 Vaccine-induced protection against Helicobacter pylori in mice lacking both antibodies and interleukin-4. Infect Immunol 71:3628-3633 